\title{
Production of first- and second-generation ethanol for use in alcohol-based hand sanitizers and disinfectants in India
}

\author{
Meenu Hans ${ }^{1,2} \cdot$ Yogita Lugani $^{3} \cdot$ Anuj K. Chandel $^{4} \cdot$ Rohit Rai $^{5} \cdot$ Sachin Kumar $^{1}$ (D) \\ Received: 16 January 2021 / Revised: 27 April 2021 / Accepted: 27 April 2021 \\ (C) The Author(s), under exclusive licence to Springer-Verlag GmbH Germany, part of Springer Nature 2021
}

\begin{abstract}
Emergence of "severe acute respiratory syndrome coronavirus 2 (SARS-CoV-2)" causing "COVID-19" or "coronavirus disease 19" as pandemic has got worldwide attention towards hygiene as the first line of defense for the infection control. It is first line of defense not only from COVID-19 but also from other infectious diseases caused by deadly pathogens such as cholera, hepatitis, tuberculosis, polio, etc. Absence of any particular vaccine or treatment let World Health Organization (WHO) recommend to the public to maintain social distancing along with regularly washing their hands with soap, sanitize their hands (where washing is not possible), and disinfect their belongings and buildings to avoid the infection. Out of various formulations available in the market, WHO has recommended alcohol-based hand sanitizers, which mainly comprise of ethanol, isopropyl alcohols, and hydrogen peroxides in different combinations due to their high potential to kill the broad range of pathogens including bacterial, viral, fungal, helminthes, etc. Therefore, alcohol-based sanitizers are in high demand since centuries to prevent infection from pathogenic diseases. Ethanol is the most common and popular alcohol in terms of vanishing wide range of pathogens, convenient to use and its production. Ethanol is produced worldwide and is used in various sectors, e.g., beauty and cosmetics, food and beverages, and as the most demanding gasoline additive. The present review is focused on the ethanol production in India, its diversified applications emphasizing hand sanitizers with discussions on formulation of sanitizer and disinfectants, and viability of lignocellulosic and food grain-based ethanol. The review article also emphasizes on the technological details of $1 \mathrm{G}$ and $2 \mathrm{G}$ ethanol production, their associated challenges, and inputs for the improved ethanol yields so as to strengthen the supply chain of ethanol in India, and making "Atmanirbhar Bharat" (Self-reliant India) campaign of Indian government successfully viable.
\end{abstract}

Keywords Sanitizer $\cdot$ Disinfectant $\cdot$ Ethanol $\cdot$ Lignocellulosic biomass $\cdot$ Infectious disease

Meenu Hans and Yogita Lugani have equal contribution as first author.

Anuj K. Chandel

anuj10@usp.br; anuj.kumar.chandel@gmail.com

Sachin Kumar

sachin.biotech@gmail.com; sachin.kumar20@gov.in

1 Biochemical Conversion Division, Sardar Swaran Singh National Institute of Bio-Energy, Jalandhar-Kapurthala Road, Wadala Kalan, Kapurthala, Punjab 144601, India

2 Department of Microbiology, Guru Nanak Dev University, Amritsar, Punjab 143005, India

3 Department of Agriculture and Environmental Sciences, National Institute of Food Technology Entrepreneurship and Management (NIFTEM), Sonepat, Haryana 131028, India

4 Department of Biotechnology, Engineering School of Lorena (EEL), University of São Paulo, Lorena, SP, Brazil

5 Faculty of Applied Medical Sciences, Lovely Professional University, Phagwara, Punjab 144411, India

\section{Introduction}

Hygiene is an important practice to keep human as well as its belonged living organisms healthy on the earth to avoid pathogenic diseases for centuries. Regularly emerging pathogens belonging to bacterial, viral, protozoan, or other phyla of animal or plant kingdom responsible for the diseases like cholera, chickenpox, measles, polio, hepatitis, and tuberculosis have posed severe challenges to the community health worldwide for a long time. Recently encountered pathogen "severe acute respiratory syndrome coronavirus 2" (SARS-CoV-2) has caused worldwide pandemic coronavirus disease 2019 (COVID-19) [1]. It is a well-known deadly virus with total number of infections and deaths as $136,136,860$ and $2,941,349$, respectively, worldwide and $13,358,805$ and 169,305, respectively in India as on April 11, 2021 [1,2].

Though the emergence of several effective vaccines for this newly emerged disease made some relief in the society, but 
there are still the preventative guidelines need to be followed to control the outbreak of deadly disease, which are social distancing, and hygiene through cleanliness via regularly washing hands or their sanitization, and disinfection of buildings in public areas, e.g., hospitals, railway station, airport, banks, schools, and colleges, as recommended by the "World Health Organization" (WHO) [3]. Thus, the use of sanitizers and disinfectants for sanitizing the hands or human belongings and disinfecting the buildings, respectively, is the primary preventive measure of avoiding this deadly disease, COVID-19. Therefore, during this pandemic, the demand for sanitizers and disinfectants has increased drastically, which led to the need of safe and promising formulations to be available in the market. Other than "COVID-19," WHO has always advised to maintain hand hygiene by washing with soap as well as by using sanitizer as a first line of defense against other infectious diseases [4]. WHO has recommended regularly cleaning the hands and belongings with an efficient sanitizer with an accurate formulation (discussed later in Section 4.1) [4]. Out of a variety of commercialized formulations, the most popular and demanding formulations are alcoholbased sanitizers and disinfectants; ethyl alcohol or ethanol being the simplest and widely accepted ingredient of a promising product. In fact, ethanol is found to be more effective against viruses than other alcohols such as propanol [5]. About $42.6 \%(\mathrm{w} / \mathrm{w})$ ethanol is reported to be effective against SARS and middle east respiratory syndrome, coronavirus, ebolavirus, influenza-A-virus (H3N2, H3N8, H1N1), influenza-B-virus, human immunodeficiency virus, vaccinia virus, hepatitis $\mathrm{B}$ virus, pseudo rabies virus, toga virus, Newcastle-disease-virus, bovine viral diarrhea virus, zika virus, herpes simplex viruses type 1 and 2 type, and respiratory syncytial virus in $30 \mathrm{~s}$, whereas $73.6 \%(\mathrm{w} / \mathrm{w})$ is effective against hepatitis $C$ in 15 and $30 \mathrm{~s}[6,7]$. The brewing and distilleries in Canada have taken necessary actions to produce high quality of hand sanitizers to mitigate viral transmission for combating the spread of coronavirus during COVID-19 outbreak [8].

Ethanol is widely produced through biochemical (via fermentation) as well as thermochemical (via gasification) routes for its applications in diversified areas, e.g., cosmetics, food and beverages, pharmaceutical and transportation sector as a promising biofuel. Currently, the major producers of bioethanol are the United States of America (U.S.A) and Brazil utilizing food crops, corn and sugarcane juice, respectively as feedstock via biochemical route, and produced about 15.8 and 8.6 billion gallons of ethanol, respectively in 2019, which contributes about $89 \%$ of the world's total ethanol production [9].

In this paper, we review the current status of ethanol production in India, its diversified applications with special emphasis on hand sanitizers and disinfectants, their formulations, viability of ethanol produced from biomass refinery for development of hand sanitizers, industrial scenario, and health issues of ethanol-based sanitizers.

\section{Current status of ethanol production in India}

Bioethanol has been recognized as one of the key ingredients of cosmetics and beauty products, pharmaceutical, food and beverages, and as an oxygenated additive of gasoline. The increasing demand for ethanol to be used in various sectors with major emphasis for gasoline blending led to the installation of several ethanol distilleries in the country with most of the plants using molasses as feedstock and produced about 2.7 billion liters of ethanol in 2018 [10]. The estimated ethanol production from molasses, damaged food grains and sugarcane juice was recorded as 2.2 billion liters, 167.5 and 20 million liters, respectively in 2019 (https://apps.fas.usda.gov/ newgainapi/api/report/downloadreportbyfilename?filename= Biofuels\%20Annual_New\%20Delhi_India_8-9-2019.pdf). The ethanol produced in India is primarily consumed by the liquor industry followed by chemical industry, and other sectors [10]. A variety of feedstocks, e.g., sugarcane molasses (SCM), sugarcane juice, and food grains, are used as feedstock for producing ethanol known as first-generation (1G) ethanol (discussed later in Section 5). Currently, 330 distilleries are operating in the country with an average annual production of 4.8 billion liters of ethanol. Being the 2 nd most populated country in the world (16\% of total population), India is largely dependent on the ethanol import to fulfill even daily requirements. U.S.A is the largest ethanol exporter for 6 consecutive years followed by Pakistan, UAE, South Africa, and UK, whereas China, Netherland, and South Korea are the intermittent exporters (https://apps.fas.usda.gov/newgainapi/ api/report/downloadreportbyfilename?filename $=$ Biofuels $\%$ 20Annual_New\%20Delhi_India_8-9-2019.pdf). The annual ethanol consumption rate during last 5 years (2015-2019) was higher (14\%) than the annual production rate of ethanol (8\%). Total consumption of ethanol was recorded as 3.1 and 3 . 8 billion liters during 2018 and 2019, respectively. As a result, overall ethanol import rate was kept high in 2019 with 750 million liters, which was the maximum in the decade.

Keeping the status of ethanol production vs. consumption in the last year in view, the Indian government notified a new scheme in March, 2019 for giving financial help worth about USD 3.72 billion to sugar mills, and about USD 0.75 billion to molasses-based ethanol distilleries for enhanced ethanol production (www.india.gov.in). Lack of sufficient supply of $1 \mathrm{G}$ ethanol due to the dependence on food crops and their byproducts, and to meet daily requirements to the continuously increasing population, a wide research is taking place for second-generation $(2 \mathrm{G})$ ethanol production from lignocellulosic biomass (LCB), i.e., a non-food feedstock (discussed later in Section 5.2) [11, 12]. First of all, Biochemical Engineering Research Centre, IIT Delhi established an integrated bioprocess facility for producing 501 bioethanol per day using rice straw as a feedstock with a yield of $181.5 \mathrm{~kg}$ 
ethanol per ton of biomass with a cost of approx. USD 0.54 per liter [13]. India's first $2 \mathrm{G}$ ethanol demonstration plant using multi-feedstock, i.e., wheat straw, rice straw, bagasse, cotton stalk, bamboo, etc. with feeding capacity of 10 tons per day, was installed at India Glycols Ltd., Kashipur, Uttarakhand, in 2016. An active work is being conducted on $2 \mathrm{G}$ ethanol production with installation of a pilot plant at the National Institute for Interdisciplinary Science and Technology (NIIST) campus with a feeding capacity of $50 \mathrm{~kg}$ per day [10]. In spite of the abundant reserves of LCB in the country, technology of $2 \mathrm{G}$ ethanol production is still under development without any commercial production due to the high cost of biomass processing and technology along with complicated controlling factors of the process (discussed later in Section 5). Therefore, more research efforts are needed for the commercial success of $2 \mathrm{G}$ ethanol in India. Government of India on February 28, 2019, launched "Pradhan Mantri JI-VAN (Jaiv Indhan - Vatavaran Anukool Fasal Awashesh Nivaran) Yojana" to invest about USD 2.81 billion in $2 \mathrm{G}$ ethanol production technology in India with targeted funding for 12 commercial scale (worth USD 2.4 billion) and 10 demonstration scale (worth USD 0.2 billion) projects to be administered by Centre for High Technology including financial help of USD 26 million from 2018-2019 to 2023-2024 (www.india.gov.in).

\section{Ethanol use in diversified sectors in India}

There is a continuous rise in global ethanol production due to its remarkable applications in transportation fuels, pharmaceuticals, food and beverages, household products (paints, detergents, inks, and coatings), and cosmetics and beauty products. The global industrial demand of ethanol was 116.9 billion liters in 2019, and it is projected to grow at a compound annual growth rate (CAGR) of $2.5 \%$ to reach 135.5 billion liters by 2025 (https://www.expertmarketresearch.com/ reports/industrial-ethanol-market). The Indian ethanol market was USD 2.50 billion in 2018, which is expected to increase to USD 7.38 billion by 2024 at a CAGR of $14.5 \%$ due to its increasing use in the diversified applications (https:// www.techsciresearch.com/report/india-ethanol-market/3860. html). "Gasohol," formed by the blending of ethanol with gasoline in different ratios, is used as an automotive fuel to increase the engine efficiency, fulfill the globally rising energy demand and reduce the emission of greenhouse gases (GHGs). The oxygen content of petrol and diesel has increased after ethanol blending which improves their combustion efficiency. This biofuel is recorded as ecofriendly and more sustainable as compared to methyl tertiary butyl ether (MTBE) and ethyl tertiary butyl ether (ETBE). One of the successful achievements in the implementation of bioethanol in automotive fuel is introduction of the flexi-fuel vehicles in Brazil, which can run both on petrol and E100, i.e., bioethanol. Government of India has reported the successful trials on pilot projects for ethanol blending with fuel in India, and implemented the selling of petroleum fuel blended with $5 \%$ ethanol in nine states and four union territories from January 2003 [14]. Indian government has mandated the ethanol blending in gasoline by $10 \%$ for reducing the import of oil, and Bureau of Indian Standards (BIS) has finalized the specification of ethanol-blended gasoline to $20 \%$ for vehicular fuel [15]. Several scientific studies have proved the significant decrease in emission of toxic substances and GHGs from ethanol-petrol blends and ethanol-diesel blends [16-22].

In pharmaceutical industries, ethanol is used in filmcoating process for tablets production and as solvent to solubilize the preservatives like injections [23-25]. Different organic solvents such as ethanol, acetone and isopropanol have been utilized in the formulation of tablets and capsules during wet granulation process and film-coating process [26-28]. Ethanol (95\%, v/v) is widely used as a carrier for a wide spectrum of medicines like iodine solutions, decongestants cough [29]. The pharmaceutical organic solvent market is expected to grow at a CAGR of $4.4 \%$ from 2020 to 2030 , and ethanol is used for high-quality tablet coatings, OTC drugs, and syrups. After considering the environmental issues caused by the use of toxic chemicals used in drug formulations, the United States Environmental Protection Agency (USEPA) has focused on need of greener chemical processes in the pharmaceutical solvents sector (https://www.futuremarketinsights.com/ reports/pharmaceutical-solvents-market). Ethanol is used in hand sanitizers in combination with isopropanol and benzyl chloride to combat pandemic diseases like COVID-19 as approved by Food and Drug Administration (FDA), U.S.A [8].

In food industries, ethanol is the primary ingredient of various alcoholic beverages such as beer, wine and spirits (vodka, grappa, gin, whiskey, tequila, caipirinha), fruit juices, salads, candies, burger rolls, sweet milk rolls, and fermented foods like yogurt and bread [29-32]. The composition of ink-jet cartridge has ethanol (at least $70 \%$ by weight), a colorant, a conductive agent, and a binder [33]. A liquid hand dishwashing detergent containing ethanol/ benzyl alcohol was patented by Tajmamet and his research team, and this product was commercialized by the Procter \& Gamble Company, Cincinnati, OH (U.S.A) [34]. Phenoxyethanol has broad-spectrum of antimicrobial activity, and hence, it has been widely used as a preservative in cosmetic and skin-care products. It is also used in the fragrance mixtures in perfumes and deodorants [35]. Ethanol is used as a preferred solvent for extraction of fatty acids in bilayer oil paint models [36]. 


\section{Sanitizer and disinfectant formulations and their use}

The effectiveness of hand sanitizer is variable, and utilized for the infection control against a broad range of pathogens in different areas dealing with public, for example, schools, hospitals, healthcare clinics, supermarkets, etc. Hand sanitizers as well as disinfectants exist with various compositions as discussed ahead.

\subsection{Use of ethanol in hand sanitizer}

Though a number of hand sanitizers are available in the market with various compositions, but basically sanitizers fall into two categories, alcohol-based hand sanitizers (ABHS) and non-alcohol-based hand sanitizers (NABHS). A sanitizer of any of these categories comprises active and inactive ingredients [5]. Table 1 summarizes the composition of various sanitizers available in the market. The primary active ingredient of ABHS is alcohol, which can include $60-95 \%(\mathrm{v} / \mathrm{v})$ ethanol, isopropyl alcohol, $n$-propanol, providone-iodine (PVP-I), chlorhexidine, or their combinations [1, 13, 37]. Alcohols help in preventing pathogen's infection by killing microbial cells via penetration and disruption of cell membrane, denaturation of proteins, and inhibiting or uncoupling of mRNA and protein synthesis via interrupting structure or functions of ribosomes and RNA polymerase [38]. Alcohols act against enveloped viruses; thus, their anti-viral activity is specific for the viral envelops (adenoviruses, noroviruses, and rotaviruses) which are specifically made up of lipids, and perform all life functions inside the host cells; however, exact anti-viral mechanism of alcohols is not well-known [5, 39]. Furthermore, the effectiveness of ethanol with addition of acids increases against those viruses, which are resistant to only ethanol preparation [6]. However, this synergy of ethanol and acid is found to be ineffective against nonenveloped viruses. PVP-I or iodopovidone is a complex of povidone (polyvinyl pyrrolidone), hydrogen iodide, and elemental iodine, completely soluble in cold and lukewarm water, and some of the short-chain alcohols (e.g., ethyl alcohol, isopropyl alcohol), polyethylene glycol, glycerol, etc. and displays microbicidal activity against broad range of pathogens including bacteria, viruses, fungi, and protozoa [40]. The mode of action of PVP-I against microbial cells is the iodination of lipids and oxidation of cellular compounds by free iodine liberated from the complex and results into cell death. Chlorhexidine also known as chlorhexidine gluconate (CHG) or chlorhexidine acetate is a biguanide compound, and is commonly used as an antiseptic for surgery, and disinfectant to sterilize the surgical instruments [41]. It is effective against broad range of microorganisms, but not spores.
The mode of action of chlorhexidine includes the release of positively charged chlorhexidine cation from the compound by dissociation of chlorhexidine salts, which binds to the negatively charged bacterial cell walls causing bacteriostatic effect, i.e., stops the cell's multiplication instead of killing at low concentrations, whereas at high concentrations, causes cell death by precipitation or coagulation of proteins and nucleic acids via disrupting cytoplasmic and inner membrane of the cell $[42,43]$. The inactive components of an ABHS include humectants (such as glycerin for liquid rubs) aid in the prevention of skin dehydration; excipients assist in increasing the biocidal activity of sanitizer by stabilizing the product and extending the time of evaporation of alcohol, propylene glycol and essential oils from plants, etc. [5, 44]. Furthermore, the primary active ingredient of NABHS is benzalkonium chloride, a quaternary ammonium, a commonly used disinfectant $[5,44]$. It is considered to be generally less irritating than alcohol, however can cause contact dermatitis [45]. ABHS are used worldwide due to better efficacy of reducing pathogenic transmission and lower cost than NABHS (https://www. cadth.ca/sites/default/files/external_rr_12_12_5_process.pdf). Formulations of ABHS recommended by WHO are Formulation I comprising of ethanol $80 \%(\mathrm{v} / \mathrm{v})$, glycerol 1 . $45 \%(\mathrm{v} / \mathrm{v})$, and hydrogen peroxide $\left(\mathrm{H}_{2} \mathrm{O}_{2}\right) 0.125 \%(\mathrm{v} / \mathrm{v})$, and Formulation II consisting of isopropyl alcohol $75 \%(\mathrm{v} / \mathrm{v})$, glycerol $1.45 \%(\mathrm{v} / \mathrm{v})$, and hydrogen peroxide $0.125 \%(\mathrm{v} / \mathrm{v})$ (https://www.who.int/whosis/whostat/2009/en/).

\subsection{Use of ethanol in disinfectants}

The protection of living beings and their belongings is carried out by hand sanitizer or simply sanitizer, which are mild in composition as discussed above; however, for very large surfaces and objects (specifically non-living) are sanitized or disinfected with the help of disinfectants, which are generally concentrated in formulation as compared to the sanitizers. A disinfectant is a chemical agent, which acts against broad range of microorganisms with necessary criteria of stability, very low cost, non-toxic and non-corrosive character, nonallergenic, and residual effect [46]. Disinfectants are a part of the regular use to clean floors in building premises of healthcare centers such as hospitals, kitchens and bathrooms of houses, schools and other public places; however, they are not able to kill all the microorganisms particularly bacterial spores but can still inactivate or kill a large variety of pathogens, thus provide a large-scale protection. The mode of function of disinfectants to destroy the microorganisms is by rupturing their cell wall by damaging the proteins and interrupting their metabolism. Disinfectant formulations are registered with the Environmental Protection Agency (EPA). Most EPA-registered disinfectants label the claim of their effect in killing or inactivating pathogens in $10 \mathrm{~min}$ [47]. However, effectiveness of these disinfectants against variety 





of bacteria, yeasts, and viruses can be observed in 30-60 s [48]. As in sanitizers, active ingredients are also aided in disinfectants for the supportive functions such as surfactants for consistent wetting on the surface aid in easy cleaning, e.g., dodecanoic acid (coconut soap) in solution of alcohol. There is a broad range of disinfectants used in different areas with different purposes such as air disinfectants (chemicals suspended in the air, e.g., propylene glycol, triethylene glycol); alcohols (e.g., ethanol, IPA); aldehydes (e.g., formaldehyde, glutaraldehyde); oxidizing agents (e.g., electrolyzed water, hydrogen peroxide ); peroxy and peroxo acids (e.g., peroxyformic acid, peracetic acid); phenolics (e.g., phenol, chloroxylenol); quaternary ammonium compounds (e.g., benzalkonium chloride); inorganic compounds (e.g., sodium hypochlorite, potassium hydroxide), and nonchemical (e.g., ultraviolet germicidal irradiation). Out of these, alcohol-based disinfectants are the most commonly used due to the effectiveness and low cost. Table 2 summarizes the composition of various disinfectants available in the Indian market. Most of the alcohol-based products are formulated with low concentrations of other supportive agents, for example, chlorhexidine, which aids in improving efficiency of sanitizers by decreasing its evaporation time from the surface [49].

However, effectiveness of alcohols against the microbial cells is only in the presence of water; for instance, absolute alcohol $(100 \%)$ is not considered effective against microorganisms as it can denature proteins only of external membrane. Alcohols can only diffuse through the cell membrane with the help of water, i.e., their solution in distilled water, e.g. , a solution of 70\% ethanol or IPA in water is effectual against a wide range of pathogens [50]. Among alcohols, IPA kills bacteria effectively but is less active against hydrophilic viruses (e.g., poliovirus), which are destroyed by ethyl alcohol efficiently [49]. High-concentration mixtures of ethanol and IPA, for example, $80 \%$ ethanol and 5\% IPA, can efficiently inactivate the lipid-enveloped viruses, e.g., HIV, hepatitis B, and hepatitis C. Furthermore, an efficacy of 29. $4 \%(\mathrm{v} / \mathrm{v})$ ethanol along with dodecanoic acid acts against a broad range of pathogens.

\section{Technological details for ethanol production}

\subsection{First-generation ethanol}

$1 \mathrm{G}$ ethanol is produced primarily from food crops and byproducts of their processing such as sugarcane (juice, molasses), grains (maize, wheat), and tuber crops (potato, sugar beet). However, $1 \mathrm{G}$ ethanol is categorized based on sugary and starchy feedstocks as discussed ahead, and process of
$1 \mathrm{G}$ ethanol production from sugary as well as starchy feedstocks is presented in Fig. 1.

\subsubsection{Sugary feedstocks}

The sugary feedstocks are those which contain simple sugars or monosaccharides (glucose or fructose) or disaccharides (sucrose or saccharose), which can be extracted with water by simple technology, and fermented directly using a potential microbial strain (e.g., Saccharomyces cerevisiae) without any additional processing (Fig. 1a). Fermenting strain converts sucrose (one of the important disaccharides contained in $1 \mathrm{G}$ feedstocks) into monomeric units, glucose, and fructose that are reducing sugars with the help of enzyme invertase. Sugar crops are primarily cultivated for sugar production, and secondarily for alcohol production, though it largely depends on the availability versus demand profile of sugar and ethanol [51]. The two main sugar crops grown commercially for sugar production are sugarcane and sugar beet, which have a contribution of 80 and 20\%, respectively, in the sugar market [52]. According to the Food and Agriculture Organization (FAO) of the United Nations, sugarcane is utilized for sugar production by 71 countries, sugar beet is utilized by 43 countries, and on the other hand, 9 countries utilize both the crops for sugar production. The primary and traditional source of ethanol worldwide is sugarcane of which juice and molasses are utilized for this purpose. It is an abundant and sustainable resource in sugar and fuel industry, largely grown in the tropical and subtropical countries with worldwide production about 1.91 billion tons. According to FAO, 2019 Brazil contributes about $39 \%$ (746.8 million tons) of the total sugarcane production followed by $20 \%$ from India (376.9 million tons) and $6 \%$ from China (108 million tons) and Thailand (104 million tons).

Sugarcane molasses (SCM) is the most traditional feedstock for ethanol production in Brazil and India, which is a dark brown liquid obtained as a by-product during sugarrefining process. A good amount of sugar (50-60\%) remains in SCM affecting the revenue of the process adversely, which necessitates its sugar content to be converted into ethanol to take full advantage of sugarcane [53, 54]. SCM is comprised of $80-85^{\circ}$ brix, $44-60 \%$ total sugars, $31-34 \%$ sucrose, $16-$ $17 \%$ reducing sugars, $12.69 \%$ ash (wet weight), amino acids, and minerals e.g., 300-12000 ppm potassium, 150-2000 ppm calcium, and 80-3900 ppm magnesium with $\mathrm{pH}$ of 5-5.8 [54]. High sugar content of SCM has made them as primary source of $1 \mathrm{G}$ bioethanol production in countries such as India, China, and Brazil. India is one of the largest producers of SCM with an average production of 12.3 million tons during 2015-2018 (4.6 million tons in 2018 ) with about $38-48 \%(\mathrm{w} / \mathrm{v})$ of fermentable sugars, which could lead to 200-290 1 of ethanol $(95 \% \mathrm{v} / \mathrm{v})$ from 1 ton of molasses [55]. A study was reported for fermentation of SCM containing $390 \mathrm{~g} / 1$ total sugars with 


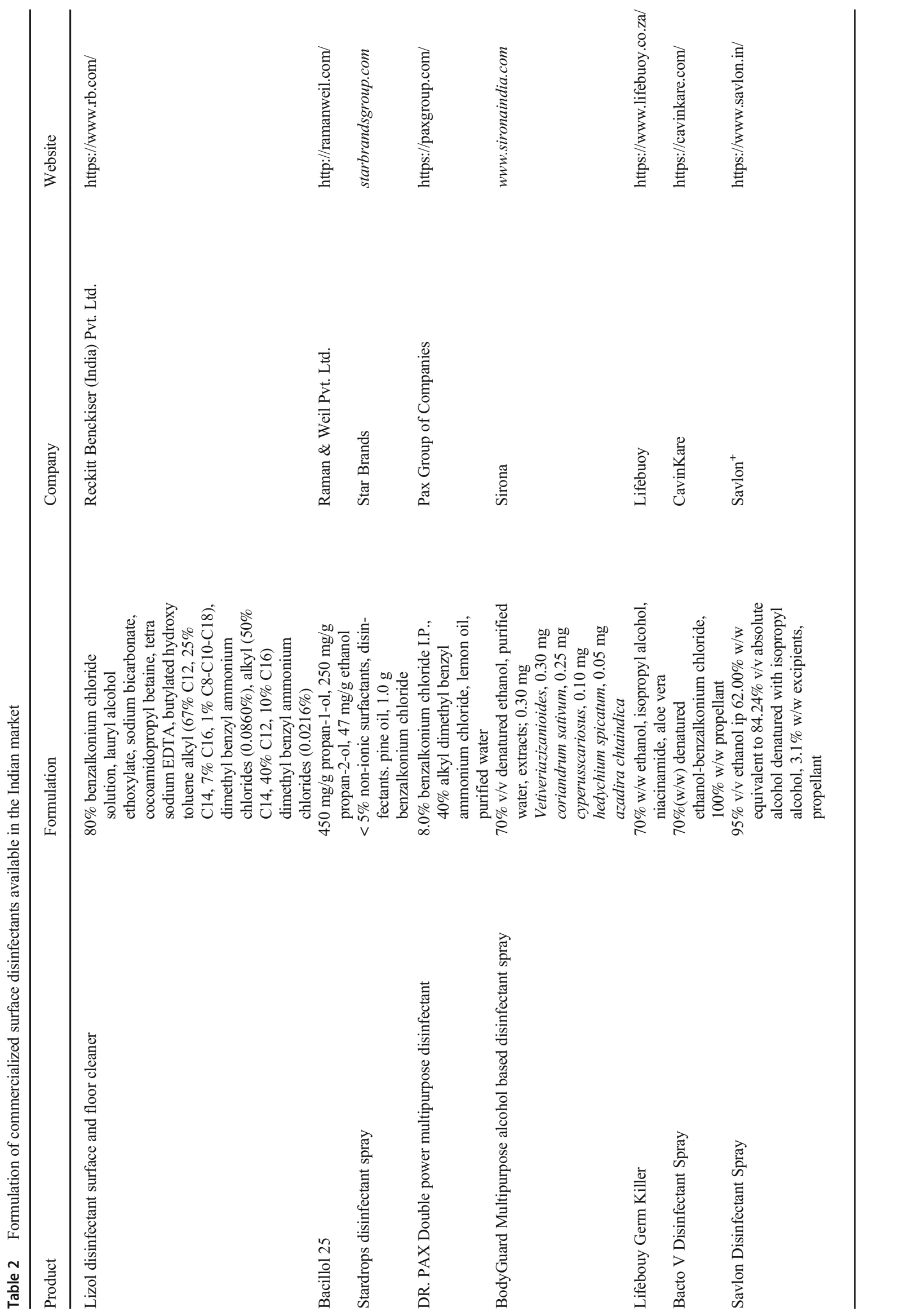


Fig. 1 Process of $1 \mathrm{G}$ ethanol production a from sugary feedstocks and $\mathbf{b}$ from starchy feedstocks; AMG: Amyloglucosidase

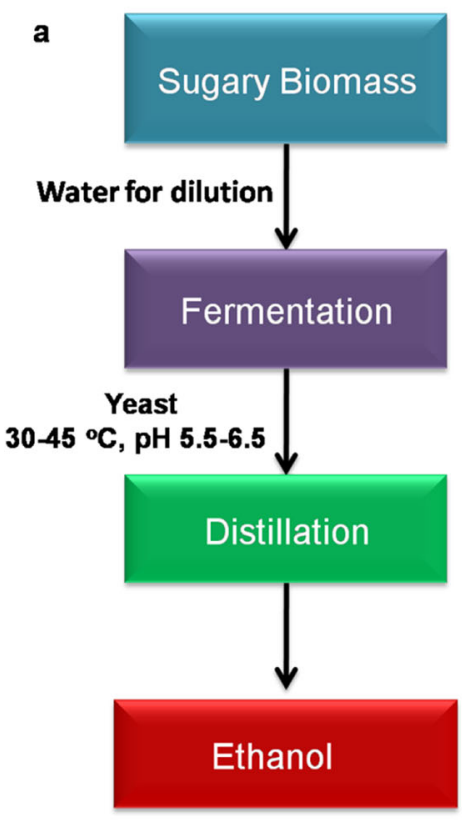

b
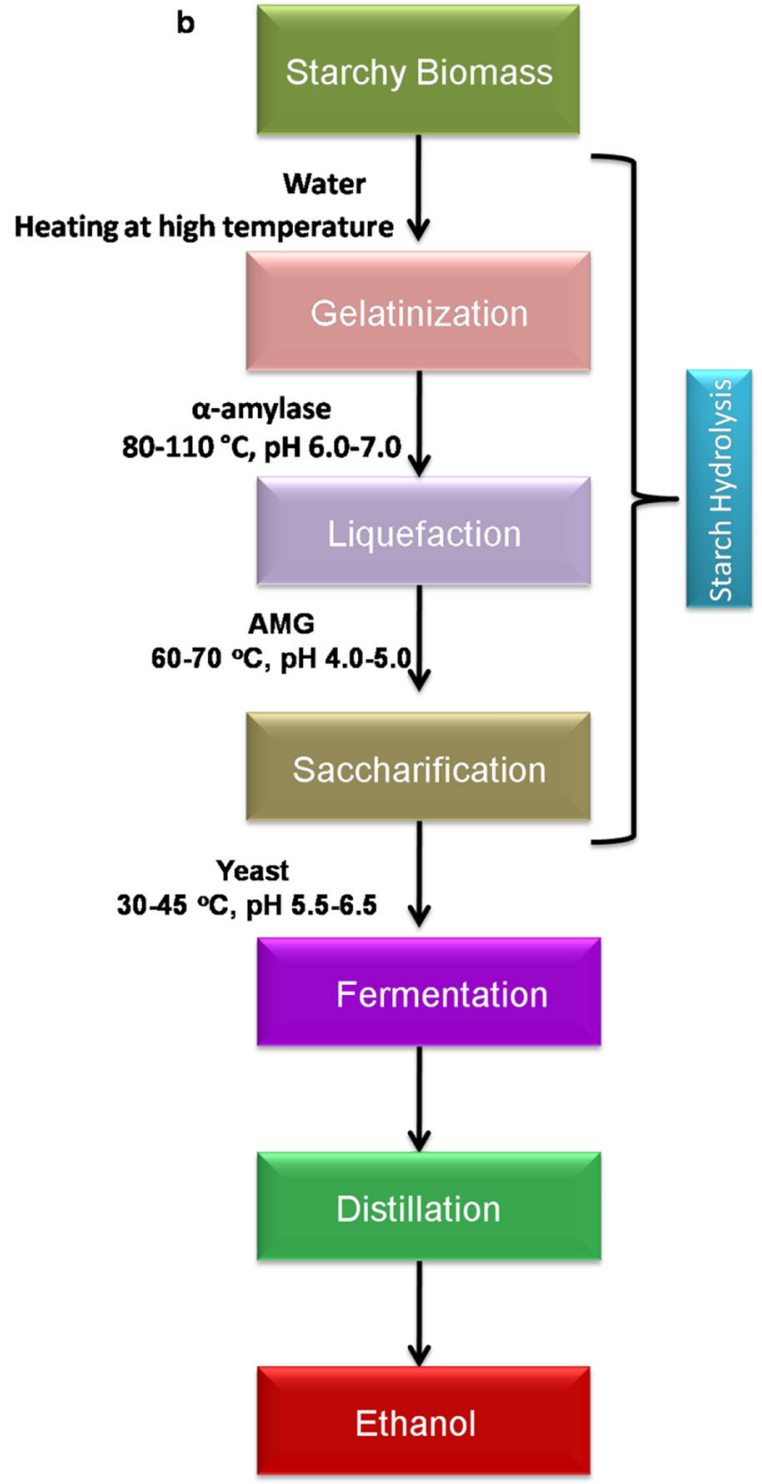

optimum urea (nitrogen source) and inoculum (S. cerevisiae) dosage at 4 and $0.5 \mathrm{~g} / \mathrm{l}$, respectively, at $35^{\circ} \mathrm{C}$ resulting into an ethanol concentration of $87 \mathrm{~g} / \mathrm{l}$ with a fermentation efficiency of $85.12 \%$ [56]. Maiti, Rathore, Srivastava, Shekhawat, and Srivastava [57] investigated another study of fermentation of SCM containing initial total sugars of $216 \mathrm{~g} / \mathrm{l}$ using $10 \%(\mathrm{v} / \mathrm{v})$ inoculum size (Zymomonas mobilis 2427) at $31{ }^{\circ} \mathrm{C}$, and reported maximum ethanol yield of $59.59 \mathrm{~g} / \mathrm{l}$ after $44 \mathrm{~h}$. More recently, Wu, Chen, Cao, Lu, Huang, Lu, Chen, Chen, Guan, and Wei [53] studied the SCM fermentation with $70^{\circ} \mathrm{C}$ Brix value using industrially engineered strain $S$. cerevisiae MF01PHO4 with $2 \times 10^{8}$ cells $/ \mathrm{ml}, 0.2 \%(\mathrm{w} / \mathrm{w})$ urea, and $0.02 \%$ (w/w) phosphoric acid at $30{ }^{\circ} \mathrm{C}$, and reported a maximum ethanol yield of $114.71 \mathrm{~g} / 1$ after $24 \mathrm{~h}$ [53]. Another sugarrich feedstock which has been well studied for $1 \mathrm{G}$ ethanol production is sweet sorghum, which provides high ethanol yield per hectare (ha) of cultivation. The yield of sugary rich stalk of sweet sorghum is 3-7 ton/ha, which is mainly utilized for fermentation (1G ethanol) out of the whole plant. Brix and sugar contents of sweet sorghum juice are in the range of 1621 and $15-22 \%$, respectively, depending on the variety, and exhibits potential of up to 10,600 1 of ethanol/ha of sweet sorghum [58-60]. Brix content and biomass yield of sweet sorghum are less than sugarcane but water and fertilizer requirements for its cultivation are $1 / 3 \mathrm{rd}$ of sugarcane [61]. Juice extracted from sweet sorghum stalk comprising of sucrose, glucose, and fructose is screened to remove any particulate matter with subsequent sterilization, and is submitted for fermentation using suitable strain, e.g., S. cerevisiae. Ratnavathi, Suresh, Kumar, Pallavi, Komala, and Seetharama [60] reported $90 \mathrm{~g} / 1$ ethanol through the fermentation of sweet sorghum juice containing $200 \mathrm{~g} / \mathrm{l}$ sugars using $2 \%(\mathrm{v} / \mathrm{v})$ cells of $\mathrm{S}$. cerevisiae at $30{ }^{\circ} \mathrm{C}$ in $60 \mathrm{~h}$. There is another study of fermentation of sweet sorghum juice 
containing $191 \mathrm{~g} / 1$ sugars using $1 \times 10^{8} / \mathrm{ml}$ cells of S. cerevisiae at $30{ }^{\circ} \mathrm{C}$ resulting into ethanol concentration and yield as $82 \mathrm{~g} / 1$ and $0.42 \mathrm{~g} / \mathrm{g}$ total sugars consumed, respectively, which corresponds to $82.2 \%$ of the theoretical yield [58]. Fernandes, Braga, Fischer, Parrella, de Resende, and Cardoso [62] studied fermentation of juices of sweet sorghum with sugar concentration of $158.2 \mathrm{~g} / \mathrm{l}$ using $30 \mathrm{~g} / \mathrm{l}$ cells of $S$. cerevisiae $\mathrm{Y} 940$ at $35^{\circ} \mathrm{C}$ resulting into ethanol concentration of $72.3 \mathrm{~g} / 1$ and ethanol yield of $0.46 \mathrm{~g} / \mathrm{g}$ total sugars consumed in $8 \mathrm{~h}$. Apart from juice, other parts of $1 \mathrm{G}$ feedstocks e.g., sweet sorghum stem comprising of lignocellulosic composition, are utilized for $2 \mathrm{G}$ ethanol production as discussed later.

\subsubsection{Starchy feedstocks}

Starch-based feedstocks are comprised of storage polysaccharides in the form of starch, which in turn is formed of two chains of glucose, straight-chained amylose $(\alpha-1,4)$ and branched amylopectin $(\alpha-1,4$; branching at $\alpha-1,6)$ forming $34-38$ and $70-85 \%$ of total starch, respectively. The conversion of this complex polysaccharide requires hydrolysis of starch into fermentable sugars via (i) heating step, i.e., gelatinization comprising of heating the substrate in raw, powered form or chips along with water to enhance the enzyme accessibility towards it, (ii) liquefaction using $\alpha$-amylase at high temperature, which hydrolyzes the $\alpha-1,4$ linkage of starch causing the release of maltose, dextrin, maltopentoses, and maltotriose, and (iii) complete hydrolysis using amyloglucosidase (AMG), which breaks down the $\alpha-1,4$ as well as $\alpha-1,6$ linkages of starch resulting into the release of glucose along with other free soluble sugars if any, followed by the fermentation using selected microbial strain (Fig. 1b) [63]. However, gelatinization step is not necessary as reported by some researchers that it does not impact much on the hydrolysis rate of starch [64].

A variety of starch-containing feedstocks, e.g., corn, wheat, other grains, cassava, and sweet potato, are available, which are conventionally used in $1 \mathrm{G}$ ethanol production. The most important and leading starchy food crop used as ethanol feedstock is corn. The world's leading producer of ethanol, U.S.A produces $95 \%$ of its total ethanol using corn as the feedstock, and produced about 15.8 million gallons of ethanol during 2016 , which was $54.3 \%$ of overall global ethanol production (29.1 million gal) (www.statista.com). Annual production of corn was about 1.04 billion ton during 2016-2017, U.S.A being the leading producer of corn contributed $37 \%$, i.e., more than one-third of the world's production followed by China (21.2\%) and Brazil (8.3\%) [65]. The world's ethanol production from corn was almost doubled during 2007-2016. Corn is widely popular and highly successful crop worldwide with $72 \%$ starch, $9.5 \%$ fiber, $9.5 \%$ protein, and $4.3 \%$ oils, and is not only used as food, livestock feed, and feedstock for ethanol production but also for various industrial products $[66,67]$.

Wheat is the second most widely used food grain utilized for ethanol production after corn. Annual production of wheat was 737.83 million metric tons in 2017 with European Union as the leading producer providing an average production of 150 million tons annually; however, individual countries, which are the leading producer of wheat, are China (130 million tons), India ( 90 million tons), and Russia (70 million tons) [65]. The average yield of wheat is about 3.4 tons/ha, which is almost half of that of corn ( 5.7 tons/ha). About $3 \%$ of total ethanol produced in U.S.A is from wheat after corn [65].

Other starch-containing food crops are tuber crops; for instance, cassava is the 5th most significant starch-containing food crop in the world with 70-90\% starch content grown in the tropical and subtropical regions [68]. The annual production of cassava is approximately 250 million tons with the largest production in the African region providing 50\% of the world's production, and Nigeria is the leading producer country with the annual production of more than 50 million tons [69]. Apart from its use in food and feed industry, cassava is widely used for ethanol production in countries like China, Thailand, and Vietnam in the form of dried chips, which are stored for longer use in the plant [70]. In a study, hydrolysis of cassava starch with enzyme derived from bacteria Laceyell asacchari LP175 supplemented with commercial glucoamylase was investigated at $50^{\circ} \mathrm{C}$ for $12 \mathrm{~h}$ resulting into sugar concentration of $157 \mathrm{~g} / 1$ with $66 \%$ hydrolysis rate, and subsequent fermentation of obtained sugars using S. cerevisiae $\mathrm{M} 30$ at $50{ }^{\circ} \mathrm{C}$ for $6 \mathrm{~h}$ followed by fermentation with $K$. marxianus DMKU-KS07 at $42{ }^{\circ} \mathrm{C}$ for $18 \mathrm{~h}$ resulting into $90.9 \mathrm{~g} / \mathrm{l}$ ethanol concentration, which corresponds to $88 \%$ of theoretical yield and ethanol productivity of $3.79 \mathrm{~g} / \mathrm{l} / \mathrm{h}$ [71]. In another study, hydrolysis of cassava starch to glucose was done by using cultures of Loog-Pang (Thai rice cake inoculum) immobilized on thin shell silk cocoon at $35^{\circ} \mathrm{C}$ for $120 \mathrm{~h}$ resulted into glucose concentration of $145.5 \mathrm{~g} / 1$ with subsequent fermentation using $5 \%(\mathrm{v} / \mathrm{v})$ cells of $S$. cerevisiae $\mathrm{M} 30$ at $33{ }^{\circ} \mathrm{C}$ for $72 \mathrm{~h}$, and reported ethanol concentration of $71.2 \mathrm{~g} / 1$ [72].

Sweet potato is another starch-enriched food crop with about $24.6-83.7 \%$ starch content along with 3.6-29.6\% simple sugars, e.g., glucose, fructose, and sucrose providing it a sweet taste [73]. It is a promising feedstock for ethanol production, grown as a perennial crop in the tropical and subtropical regions and as an annual crop in the temperate regions. It is the world's 7th most significant food crop with the major use in the energy sector and as a phytochemical source of nutrition [74]. The annual production of sweet potato is about $2-15$ ton/ha. Asia and Africa provide more than $90 \%$ sweet potato production in the world. China is the largest producer of sweet potato contributing $67 \%$ of the world's production followed by Indonesia, Vietnam, India, and so on $[75,76]$. 
Due to high starch content (24.6-83.7\%), significant content of simple sugars (3.6-29.6\%), and good agricultural yield (215 ton/ha), sweet potato is mainly cultivated not for food but for energy sector particularly for ethanol production. Some of the industrial varieties of sweet potato possess the potential of ethanol yield as 4500-6500 l/ha [72, 77]. Preparation of sweet potato prior to bioprocessing into ethanol includes first chopping into small chips followed by crushing into powdered form by milling. Zhang, Zhao, Gan, Jin, Gao, Chen, Guan, and Wang [77] reported fermentation of raw sweet potato via liquefaction using $\alpha$-amylase (Liquozyme Supra, Novozymes China) with loading of $0.12 \mathrm{KNU}$ (Kilo Novo alpha-amylase Unit)/g substrate at $85^{\circ} \mathrm{C}, \mathrm{pH} \mathrm{5.3,20} \mathrm{min,} \mathrm{saccharification}$ with glucoamylase (Aspergillus niger) loading of $1.6 \mathrm{AGU}$ (Amyloglucosidase unit)/g substrate for $3 \mathrm{~h}$ at $60{ }^{\circ} \mathrm{C}$, and fermentation of obtained $28 \%(\mathrm{w} / \mathrm{v})$ carbohydrates in substrate using $7 \%(\mathrm{v} / \mathrm{v})$ cells of $S$. cerevisiae CCTCC M206111 at $30{ }^{\circ} \mathrm{C}$, which resulted into the maximum ethanol concentration, yield, and productivity as $128.51 \mathrm{~g} / 1,91.4 \%$, and $4.76 \mathrm{~g} / \mathrm{l} / \mathrm{h}$, respectively, after $27 \mathrm{~h}$. In a similar study, ethanol production was studied from sweet potato containing $75 \%(\mathrm{w} / \mathrm{v})$ total sugars via liquefaction using $5.4 \mu \mathrm{l}$ of $\alpha-$ amylase (Liquozyme ${ }^{\circledR} \mathrm{SC}$, Novozymes) at $86^{\circ} \mathrm{C}$, saccharification using $5.4 \mu \mathrm{l}$ AMG (Spirizyme ${ }^{\circledR}$ Fuel, Novozymes) at $60{ }^{\circ} \mathrm{C}$, and fermentation using $1 \times 10^{8} / \mathrm{ml}$ cells of $S$. cerevisiae at $30^{\circ} \mathrm{C}$, resulted into ethanol concentration, yield, productivity, and fermentation efficiency of $45 \mathrm{~g} / 1,386.7 \mathrm{~g} / \mathrm{kg}$ dry substrate, $3.2 \mathrm{~g} / \mathrm{l} / \mathrm{h}$, and $84 \%$, respectively, in $16 \mathrm{~h}$ [78]. In another study, pretreatment of liquid mash of sweet potato with cellulase enzyme was investigated with loading of $8 \mathrm{U} / \mathrm{g}$ dry substrate at $50{ }^{\circ} \mathrm{C}$ for $1 \mathrm{~h}$ resulting into reduced viscosity up to $81 \%$, with subsequent liquefaction with $20 \mathrm{U} / \mathrm{g}$ dry substrate of $\alpha$-amylase (from Bacillus licheniformis) at $95{ }^{\circ} \mathrm{C}$ for $0.5 \mathrm{~h}$, and simultaneous saccharification and fermentation (SSF) by adding $200 \mathrm{U} / \mathrm{g}$ dry substrate of glucoamylase (Aspergillus niger) at $60{ }^{\circ} \mathrm{C}$ and $2 \mathrm{~g} / 1$ yeast cells (S. cerevisiae) at $30{ }^{\circ} \mathrm{C}$, and reported an ethanol concentration of $155 \mathrm{~g} / 1$ from $284.2 \mathrm{~g} / 1$ initial saccharides with an ethanol yield of $87.8 \%$ in $45 \mathrm{~h}$ [79].

\subsection{Second-generation feedstocks}

$2 \mathrm{G}$ ethanol is produced from non-food LCB, and emerging area of research due to unsustainability of $1 \mathrm{G}$ ethanol owing to its sugar- and starch-based feedstocks, which are basically food crops or their derivatives causing increased global crisis of food scarcity [80, 81]. On the other hand, LCB is a sustainable feedstock due to its abundant availability, therefore a promising feedstock for large-scale and environmentfriendly ethanol production. LCB have potential to be available as a major feedstock for the bioenergy sector [82, 83]. A total of 442 billion liters of bioethanol can be produced annually by utilizing LCB, and this number can rise to 491 billion liters (approximately 16 times higher than the global production) after utilizing all crop residues and wasted crops $[84,85]$.

In India, states with highest biomass availability per unit area are as follows: Uttar Pradesh, Punjab, Haryana, Maharashtra, West Bengal, and Tamil Nadu. Annual agroresidue production is estimated to be 103 million tons of dry matter, whereas average forest residues production rate for temperate northern countries is about $12 \%$. Biofuel policies of nations like U.S.A and EU have encouraged the growth of $2 \mathrm{G}$ ethanol at the global level causing enhanced contribution of inexpensive feedstocks towards growth of global market of ethanol [86]. The major LCB-based ethanol plants are located in Kansas, Texas, Illinois, Iowa, North Dakota and British Columbia, Minnesota and Nebraska, and Saskatchewan and Alberta. A novel environment-friendly process has been developed by Tel Aviv University, Israel, for local production of ethanol and hand sanitizers from paper and plant waste (https://phys.org/news/2020-07-low-cost-sanitizer.html). 2G ethanol plants located in India along with their capacity are summarized in Table 3.

The main components of lignocelluloses used for the bioconversion into ethanol are polysaccharides; cellulose (30$50 \%$ ), and hemicellulose (20-40\%), which are hydrolyzed into their respective monomeric sugars that are glucose and xylose (along with arabinose, mannose, galactose, etc.), respectively $[85,87]$. The presence of recalcitrant lignin (10 $20 \%$ ) in biomass hinders the accessibility of polymeric sugars for microbial utilization, which necessitates the prerequisite steps for $2 \mathrm{G}$ ethanol production that are pretreatment and enzymatic hydrolysis before fermentation [8, 85, 86]. Fermentation of monomeric sugars released after enzymatic hydrolysis is the key step using a suitable competent strain under favorable conditions. Although there is vast potential of $2 \mathrm{G}$ ethanol as the best alternative of $1 \mathrm{G}$ ethanol, which could resolve the issues related to imbalance in ethanol demand and production as well as food scarcity, however $2 \mathrm{G}$ ethanol production is a very expensive process due to which it is still under development to be commercialized successfully. One of the major steps which contribute the high cost to the process is pretreatment of biomass, which is carried out to make the cellulose and hemicellulose accessible to hydrolytic enzymes, and is proceeded through various physical, thermochemical, biological/enzymatic, or combined methods $[8,88$, 89]. Furthermore, another major step contributing higher cost to the process is hydrolysis of accessed cellulose and hemicellulose, which is accomplished by chemical agents (specifically mineral acids) or enzymes [12, 85]. However, due to hazardous, toxic, and corrosive nature of mineral acids, requirement of expensive and sensitive equipment makes them economically as well as environmentally undesirable.

On the other hand, hydrolytic enzymes, available for specific polysaccharides and their components; cellulases, and hemicellulases are conveniently used for saccharification of 


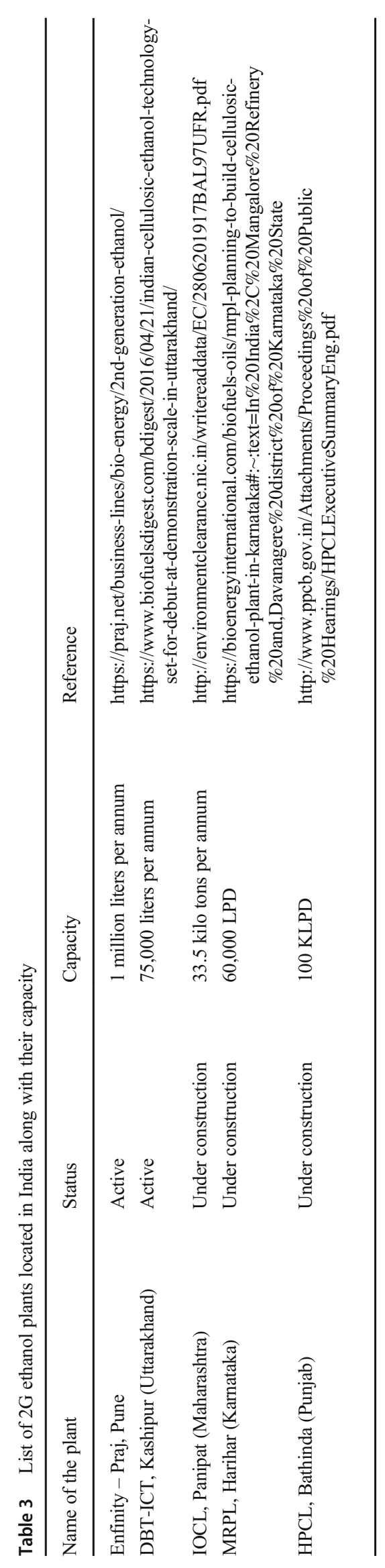


these polymeric sugars into respective monomers on account of their working under mild conditions, harmless, and noncorrosive nature [8]. In spite of efficient hydrolysis of biomass, expensive hydrolytic enzymes make the process very costly, which needs to be reduced by means of using crude enzyme preparations, lower enzyme loading, fed-batch fermentation, etc. Other major factors responsible for the high cost of process include $\mathrm{pH}$ and temperature sensitivity of hydrolytic enzyme and microbial strain, feedback inhibition by substrates/metabolites/products leading to the lower product yield, which require highly sensitive and well-equipped reactors and chemicals for $\mathrm{pH}$ and temperature maintenance as well as selection of appropriate operative strategy for $2 \mathrm{G}$ ethanol process. Various operating strategies include (i) separate hydrolysis and fermentation (SHF); (ii) simultaneous saccharification and fermentation (SSF); (iii) simultaneous saccharification and co-fermentation (SSCF); (iv) semi- or presimultaneous saccharification and fermentation (SSSF or PSSF); (v) simultaneous saccharification filtration and fermentation (SSFF); and (vi) direct microbial conversion (DMC)/consolidated bioprocessing (CBP) in a single vessel or within a single microbial strain (genetically modified) to make the process cost-effective [90].

The widely used and promising LCBs well studied for $2 \mathrm{G}$ ethanol production are sugarcane tops and bagasse, rice straw, wheat straw, other cereal residues, residues of other crops such as cotton and chilli cultivation, forest residues such as bamboo, rye, pine needles, banana stem, sunflower stalk, stem of sweet sorghum, and weeds like Saccharum spontaneum, Eicchornia crassipes, Prosopis juliflora, and Lantana camara with ethanol generating potential of 5.42 billion liters of ethanol considering 50\% conversion rate [10,91-96]. Sugarcane top is the most abundant agro-residue with annual production of 79.4 million mega ton (MMT), and is always burnt in the field itself [10]. Sugarcane bagasse (SCB) is also generated in good quantities with annual production as $1.88 \mathrm{Gt}$ in sugar industry but it is utilized for electricity co-generation in sugar mills, and paper making in pulp and paper industry. SCB has been widely studied for $2 \mathrm{G}$ ethanol production: for instance, Chandel, Antunes, Silva, and da Silva [97] reported ethanol production from liquid ammonia pretreated $(20 \%$, v/v ammonia at $70{ }^{\circ} \mathrm{C}$ for $24 \mathrm{~h}$ ) SCB via enzymatic saccharification using cellulase (Celluclast 1.5 l) and $\beta$-glucosidase (Novozyme 188) with loadings of $15 \mathrm{FPU} / \mathrm{g}$ dry biomass and $17.5 \mathrm{U} / \mathrm{g}$ dry biomass at $50{ }^{\circ} \mathrm{C}$ for $24 \mathrm{~h}$ and subsequent fermentation with Pichia stipitis ( $1 \mathrm{~g} / \mathrm{l}$, dry wt.) at $30^{\circ} \mathrm{C}$ for 96 $\mathrm{h}$, which resulted into reducing sugar concentration and yield of $28.43 \mathrm{~g} / \mathrm{l}$ and $570 \mathrm{~g} / \mathrm{kg}$ pretreated biomass (PB), respectively, and maximum ethanol concentration and yield of $10.31 \mathrm{~g} / 1$ and yield of $0.387 \mathrm{~g} / \mathrm{g}$ sugars consumed with $75.88 \%$ of fermentation efficiency. In a similar study, sodium hydroxide pretreated $\mathrm{SCB}\left(1.8 \%\right.$, w/v $\mathrm{NaOH}$ at $110^{\circ} \mathrm{C}$ for $\left.60 \mathrm{~min}\right)$ fermented via pre-hydrolysis using $10 \mathrm{FPU}$ (filter paper unit)/g substrate cellulase loading (Cellic CTec2, Novozymes) at $50{ }^{\circ} \mathrm{C}$ in $12 \mathrm{~h}$, and fermentation using $1 \mathrm{~g} / \mathrm{l}$ (dry wt.) of S. cerevisiae Y-2034 at $37^{\circ} \mathrm{C}$, and obtained maximum ethanol concentration of $31.25 \mathrm{~g} / \mathrm{l}$ in $72 \mathrm{~h}$ [98].

Next surplus biomass available for the $2 \mathrm{G}$ ethanol belongs to the cereal crops, e.g., rice straw, wheat straw, and other cereal straws with annual production of $8.5,9.1$, and 6 MMT, respectively, although as a major share of it is consumed as fodder [10]. Uttar Pradesh generates highest wheat straw (33\%) followed by Punjab, Haryana, Madhya Pradesh, and Bihar contributing more than $85 \%$ of total wheat straw production in India [94]. These agro-residual biomasses possess a vast potential of being converted into ethanol as investigated through various studies. For example, Arora, Behera, Sharma, Singh, Yadav, and Kumar [99] reported an ethanol production from alkali pretreated rice straw $(0.5 \%(\mathrm{w} / \mathrm{v})$ $\mathrm{NaOH}$ at $121{ }^{\circ} \mathrm{C}, 15 \mathrm{psi}$ for $1 \mathrm{~h}$ ) via saccharification with cellulase (A. niger) at a loading of $80 \mathrm{U} / \mathrm{g}$ PB at $45^{\circ} \mathrm{C}$ for $24 \mathrm{~h}$, and subsequent fermentation with $K$. marxianus NIRE$\mathrm{K} 3$ at $45^{\circ} \mathrm{C}$ resulting into glucose and xylose release as 10.47 and $1.85 \mathrm{~g} / \mathrm{l}$, respectively, and ethanol concentration, yield, and productivity as $3.98 \mathrm{~g} / 1,0.38 \mathrm{~g} / \mathrm{g}$ of glucose, and 0.22 $\mathrm{g} / \mathrm{l} / \mathrm{h}$, respectively, with $74.5 \%$ fermentation efficiency. In another study, bioconversion of wheat straw (pretreated by $0.9 \%$, w/w $\mathrm{H}_{2} \mathrm{SO}_{4}$, and steam explosion at $180{ }^{\circ} \mathrm{C}$ for 10 min) to ethanol via SSF was studied using $15 \mathrm{FPU} / \mathrm{g}$ dry biomass of cellulase (Celluclast 1.5 1), 12.6 IU/g dry biomass of $\beta$-glucosidase (Novozyme 188), and $0.2 \mathrm{~g} / \mathrm{l}$ cells of K. marxianus CECT 10875 at $42{ }^{\circ} \mathrm{C}$ for $72 \mathrm{~h}$ resulting into maximum sugar yield of $300 \mathrm{~g} / \mathrm{kg}$ raw straw and ethanol yield of $110.5 \mathrm{~g} / \mathrm{kg}$ raw straw [100]. Cotton, chilli, pulses, and oilseeds produce a good quantity of biomass as they are not utilized in any other potential application and could be used for ethanol production. Bamboo plant and its processing waste are also abundantly available in India with annual production of 4 and 3.3 MMT, respectively [10]. A schematic representation of production of hand sanitizers from lignocellulosicbased ethanol and their application in combating hospital and community acquired infectious diseases is given in Fig. 2.

\section{Industrial scenario of ethanol-based sanitizers in India}

There is an exponential growth in the ethanol-based hand sanitizer market in the past few years. The outbreak of global coronavirus in 2019 has led to increase the demand of hand sanitizers by $1400 \%$ all across the globe during December 2019 to February 2020. As per the report published by Fior Markets, the global market of hand sanitizers is expected to increase at a CAGR of 7.5\%, i.e., from 1.2 billion USD in 2019 to 2.14 billion USD by 2027 (https://www. globenewswire.com/news-release/2020/03/26/2007160/0/en/ 




Fig. 2 Production of ethanol-based hand sanitizers by utilizing various lignocellulosic wastes

Global-Hand-Sanitizer-Market-Is-Expected-to-Reach-USD2-14-Billion-by-2027-Fior-Markets.html).

The demand of hand sanitizers broke records in India since COVID-19 hit the country, which resulted in abrupt rise in ethanol demand. Therefore, there is a rise in ethanol production by several sugar mills conforming to the guidelines from All India Distiller Association (AIDA), and Indian Sugar Mills Association (ISMA) (https://www.marketresearch.com/ChemAnalyst-v4204/IndiaEthanol-Plant-Capacity-Production-13320153/).

\subsection{Impact of $2 \mathrm{G}$ ethanol-based sanitizer industries on economy}

India is a developing agricultural country, where abundance of agricultural raw materials, i.e., waste starchy materials (i.e., barley, corn, rice, wheat processing waste), sucrosecontaining feedstocks (i.e., sugarbeets, fruits, sugarcane), and lignocellulosic feedstocks (i.e., grasses, wood, corncob, rice straw, rice husk, wheat straw, switchgrass) are produced annually, and most of them remain unutilized and lead to the environmental pollution. From the past few years, the utilization of low-cost agricultural feedstocks (mainly LCB) has captured scientific attention for the production of $2 \mathrm{G}$ ethanol. The integrated technologies that involve the costeffective production of bioethanol include SHF, SSF/SSCF, and CBP, which have already been discussed in Section 5.2 [101]. Such lignocellulosic feedstocks also provide tremendous opportunities in the healthcare sector for the production of disinfectants and hand sanitizers. The current synthesis of ethanol for sanitizers is carried out by utilizing only molasses, and sugar mills, and it makes the market less competitive. The agricultural residues or lignocellulosic feedstocks also provide an opportunity for cost-effective production of sanitizers. A strong collaboration between government agencies, scientific institutions, universities, and agricultural and finance ministeries may help to overcome this issue. The global demand of ethanol has enhanced since 2019 after COVID-19 pandemic, and the development of an economic technology with simultaneous pretreatment, hydrolysis, and fermentation alternates for the production of low-cost disinfectants. On one hand, the utilization of lignocellulosic wastes for the production of value-added products such as bioethanol, disinfectants, and hand sanitizers helps to reduce environmental pollution caused by their improper disposal; on the other hand, their 
utilization also contributed to the nation's economy by marketing and export of these value-added products.

Red River Biorefinery (RRB), North Dakota, U.S.A, which utilizes 500,000 tons of agricultural by-products per year for the production of ethanol, has recently started producing pharmaceutical grade (USP) ethanol for production of disinfectants and hand sanitizers (http://www.prnewswire.com/newsreleases/red-river-biorefinery-now-producingpharmaceutical-grade-usp-ethanol-for-hand-sanitizers-anddisinfectants-301146352.html). Apart from specially cultivated food grains, wasted grains during transportation, processing, and storage are also utilized for ethanol refinery. Food grains have been exploited by Indian companies for ethanol production, and based on the sources utilized, Indian ethanol market has been categorized into grain-based ethanol, and mixed grain-based ethanol in addition to the molasses and sugar-based ethanol (https://www.techsciresearch.com/report/ india-ethanol-market/3860.html). The Government of India has approved the utilization of rice available with Food Corporation of India (FCI) for ethanol production at a meeting of the National Biofuel Coordination Committee (NBCC) held under the Chairmanship of the Minister of Petroleum and Natural Gas. The bioethanol, produced from rice, has aimed to be utilized for blending with petrol, and manufacturing of alcohol-based hand sanitizers (https://www.livemint. com/news/india/fci-s-surplus-rice-stocks-to-be-convertedinto-ethanol-to-make-hand-sanitisers- 11587408039897. $\mathrm{html}$ ). The central government has taken a decision to convert surplus rice lying in the warehouses of the FCI to ethanol for production of hand sanitizers to help India's fight during the COVID-19 public health emergency (https://qrius.com/indiais-using-rice-for-hand-sanitisers-as-millions-go-hungry/)

\subsection{Use of hydrated ethanol in sanitizers}

Some of the by-products present in the fermentation media during ethanol production from lignocellulosic feedstock are ketones (diacetyl), aldehydes (acetaldehyde), aromatic compounds (phenol, styrene, benzoic acid), alcohols (propanol, butanol, methylpropanol, conifer alcohol, sinapyl alcohol, pcoumaryl alcohol), fatty acids (acetic acid, propionic acid, butyric acid, butanoic acid, pentanoic acid, hexanoic acid octanoic acid, decanoic acid, dodecanoic acid), and esters (ethyl acetate, ethyl formate, propyl acetate, hexyl acetate, ethyl octanoate, ethyl dodecanoate), and these by-products need to be removed by purification to get fuel grade ethanol. The technologies used in ethanol purification are distillation, adsorption, pervaporation, and ozonation. Distillation is the most commonly used step in purification for the separation and concentration of ethanol from the azeotropic mixtures, containing two or more compounds, based on volatilities [102-104]. Sanitizers, used in healthcare sector, contain $70 \%(\mathrm{v} / \mathrm{v})$ ethanol that is less in concentration required in biorefinery area $(95.63 \%, \mathrm{v} / \mathrm{v})$. The low-concentration ethanol can be obtained from primary distillation and thereby bypass the subsequent steps of purification. The energy-demanding purification steps, required to obtain purified ethanol from binary azeotrope water-ethanol, can be omitted for the production of disinfectants, which further reduces its production cost and makes the process cost and energy efficient. Therefore, $2 \mathrm{G}$ ethanol plants can be integrated with sanitizer production plants to fulfill its global demand.

\section{Health issues of ethanol-based sanitizers}

The excessive use of hand hygiene products namely soaps and sanitizers may damage the skin by reducing the stratum corneum water-binding capacity, altering intracellular lipids, denaturing stratum corneum proteins, and decreasing the number of corneocytes [105]. These lipid-dissolving alcohols and emulsifying detergents penetrate deeper into the skin layers which result in depletion of lipid barrier and alteration of normal skin flora [106]. The use of ABHS commonly results in skin reactions including allergic contact dermatitis with manifestations of anaphylactic symptoms and respiratory distress, and irritant contact dermatitis with symptoms of erythema, dryness, bleeding, and pruritus, and these symptoms may range from mild to severe [107]. ABHS may also dry the hands, which may further lead to cracks or peeling of skin [108]. The regular application of ethanol on the skin through disinfectants results in the accumulation of small amount of ethanol and its metabolites (acetaldehyde) in blood at acute levels [109]. Ethanol-based hand sanitizers are proved to show less skin-irritant property as compared to sanitizers containing isopropanol and n-propanol [110]. Some of the common measures to prevent the skin irritation and other adverse effects of ABHS are avoiding habits that may cause skin irritation, selection of hand hygiene products with less irritating agent, and moisturizing of skin after using hand sanitizers [111, 112]. There can be inhalation and/or dermal absorption (passive alcoholism) in healthcare workers and people in hospitals due to regular use of ethanol-based hand sanitizers [113]. Similarly, the occupational use of alcohol-based antiseptics could generate detectable amount of ethanol in the blood (contributed from both inhalation and absorption of volatilized product) as proved by physiologically based pharmacokinetic and epidemiological studies [114]. Some common clinical effects such as nausea, abdominal pain, headache, loss of coordination, decreased level of consciousness, and blurred vision are observed to be similar with methanol and ethanol poisoning. Severely adverse health effects have been reported in Arizona and New Mexico with alcohol-containing hand sanitizers. There is higher risk for esophageal cancer after alcohol consumption in populations which lack in the activity of aldehyde dehydrogenase (ALD), involved in ethanol 
catabolism, compared to the populations with fully functional ALD [115]. There are several previous reports which have proved the presence of ethanol in blood and urinary ethyl glucuronide after exposure to ethanol-based hand sanitizers [116-118]. Recently, Yangzes and his coworkers have reported the ocular injury in children after using alcohol-based hand rubs [119].

\section{Conclusion}

Alcohol-based (specifically ethanol) hand sanitizers and disinfectants exhibit high potential of killing or inactivating broad range of pathogens, and led to the rise in demand of ethanol-based formulations by $1400 \%$ all across the world from December 2019 to February 2020 as reported by the WHO. They have been emerged as the first line of defense against latest SARS-CoV-2 virus and have therefore triggered the demand of ethanol manifolds. Ethanol is globally (including India) produced by using sugar- or starch-rich food crops or their processed by-products as $1 \mathrm{G}$ ethanol, and utilized as biofuel, ingredient of pharmaceuticals, household products (paints, detergents, inks, and coatings), food and beverages, and cosmetics and beauty products. Large production of $1 \mathrm{G}$ ethanol from food crops and by-products led to the major issues of food scarcity worldwide, which necessitates the exploration of non-food LCB to be utilized for $2 \mathrm{G}$ ethanol production causing a major research focused on the particular area. In India, a foreseeable amount of lignocellulosic waste is generated annually in the form of agro-residues, forestry residues, weeds etc., which is mostly burnt or left in the fields unutilized, which could be utilized for sustainable $2 \mathrm{G}$ ethanol production. Therefore, the recent paradigm of ethanol production has shifted from edible grains/molasses towards nonedible lignocellulosic feedstocks eliminating the challenges of food crisis. Moreover, the availability of LCB in abundance throughout the year offers a sustainable biotechnological solution to the escalating ethanol demand in India and across the globe. In the present time of COVID-19 outbreak, the $1 \mathrm{G}$ and $2 \mathrm{G}$ ethanol could be extremely useful to cater the burgeoning demand of hand sanitizers. This seems a viable and judicious fit in the on-going campaign of Atmanirbhar Bharat (Self-reliant India) by Government of India, which will leverage the multiple benefits to the rural and micro, small and medium enterprises driven economy.

Acknowledgements Sachin Kumar and Meenu Hans acknowledge the Department of Biotechnology, Ministry of Science and Technology, Government of India (DBT/IC-2/Indo-Brazil/2016-19/05) for the financial assistance. Meenu Hans also acknowledges Sardar Swaran Singh National Institute of Bio-Energy, Kapurthala for providing Senior Research Fellowship, and Guru Nanak Dev University, Amritsar for providing Ph.D. registration (Reg. No. 2007.KJ/A.519). Yogita Lugani acknowledges the Department of Science and Technology (DST), Ministry of Science and Technology, Government of India (SP/YO/385/2018) for the financial assistance. Anuj Kumar Chandel is grateful to CAPESBrazil for financial assistance (Process USP number: 15.1.1118.1.0).

Availability of data and material Not applicable.

Code availability Not applicable.

Author contribution Conceptualization: Anuj K. Chandel; writing - original draft preparation: Meenu Hans and Yogita Lugani; writing - review and editing: Sachin Kumar; resources: Rohit Rai; supervision: Sachin Kumar and Anuj K. Chandel.

Funding Department of Biotechnology, Ministry of Science and Technology, India (DBT/IC-2/Indo-Brazil/2016-19/05); CAPES-Brazil (Process USP number: 15.1.1118.1.0).

\section{Declarations}

Ethics approval Not applicable.

Consent to participate Not applicable.

Consent for publication Not applicable.

Conflict of interest The authors declare no competing interests.

\section{References}

1. Mahmood A, Eqan M, Pervez S, Alghamdi HA, Tabinda AB, Yasar A, Brindhadevi K, Pugazhendhi A (2020) COVID-19 and frequent use of hand sanitizers; human health and environmental hazards by exposure pathways. Sci Total Environ 742:140561

2. World Health Organization Coronavirus Disease ( COVID-19): Weekly epidemiological update - 13 April 2021 [Accessed on 15 Apr 2021]

3. World Health Organization Coronavirus Disease ( COVID-19): Advice for the public [Accessed on 28 Aug 2020]

4. World Health Organization (2009) WHO guidelines on hand hygiene in health care: first global patient safety challenge clean care is safer care. World Health Organization, Geneva

5. Golin AP, Choi D, Ghahary A (2020) Hand sanitizers: a review of ingredients, mechanisms of action, modes of delivery, and efficacy against coronaviruses. Am J Infect Control 48(9):1062-1067

6. Kampf G (2018) Efficacy of ethanol against viruses in hand disinfection. J Hosp Infect 98(4):331-338

7. Arora S, Rani R, Ghosh S (2018) Bioreactors in solid state fermentation technology: design, applications and engineering aspects. J Biotechnol 269:16-34

8. Thomson E, Bullied A (2020) Production of ethanol-based hand sanitizer in breweries during the COVID-19 crisis. Techn Quarter 57(1):47-52

9. Hans M, Kumar S, Chandel AK, Polikarpov I (2019) A review on bioprocessing of paddy straw to ethanol using simultaneous saccharification and fermentation. Process Biochem 85:125-134

10. Sukumaran RK, Surender VJ, Sindhu R, Binod P, Janu KU, Sajna KV, Rajasree KP, Pandey A (2010) Lignocellulosic ethanol in India: prospects, challenges and feedstock availability. Bioresour Technol 101(13):4826-4833

11. Kumar S, Singh SP, Mishra IM, Adhikari DK (2009) Recent advances in production of bioethanol from lignocellulosic biomass. 
Chem Eng Technol: Industr Chem-Plant Equip-Process EngBiotechnol 32(4):517-526

12. Kumar S, Dheeran P, Singh SP, Mishra IM, Adhikari DK (2015) Continuous ethanol production from sugarcane bagasse hydrolysate at high temperature with cell recycle and in-situ recovery of ethanol. Chem Eng Sci 138:524-530

13. Ghosh P, Ghose TK (2003) Bioethanol in India: recent past and emerging future. In: Biotechnology in India II. Springer, Berlin, Heidelberg, 85:1-27

14. Saini MK, Garg N, Singh AK, Tyagi AK, Niyogi UK, Khandal RK (2010) Ethanol blended fuel in India: an overview. J Biofuels 1(2):209-219

15. Sakthivel P, Subramanian K, Mathai R (2018) Indian scenario of ethanol fuel and its utilization in automotive transportation sector. Resour Conserv Recycl 132:102-120

16. Poulopoulos S, Samaras D, Philippopoulos C (2001) Regulated and unregulated emissions from an internal combustion engine operating on ethanol-containing fuels. Atmos Environ 35(26):4399-4406

17. Leong ST, Muttamara S, Laortanakul P (2002) Applicability of gasoline containing ethanol as Thailand's alternative fuel to curb toxic VOC pollutants from automobile emission. Atmos Environ 36(21):3495-3503

18. Magnusson R, Nilsson C, Andersson B (2002) Emissions of aldehydes and ketones from a two-stroke engine using ethanol and ethanol-blended gasoline as fuel. Environ Sci Technol 36(8): 1656-1664

19. Niven RK (2005) Ethanol in gasoline: environmental impacts and sustainability review article. Renew Sust Energ Rev 9(6):535-555

20. Lin W-Y, Chang Y-Y, Hsieh Y-R (2010) Effect of ethanolgasoline blends on small engine generator energy efficiency and exhaust emission. J Air Waste Manage Assoc 60(2):142-148

21. Ahmed MA, Rehman MSU, Terán-Hilares R, Khalid S, Han J-I (2017) Optimization of twin gear-based pretreatment of rice straw for bioethanol production. Energy Convers Manag 141:120-125

22. Tibaquirá JE, Huertas JI, Ospina S, Quirama LF, Niño JE (2018) The effect of using ethanol-gasoline blends on the mechanical, energy and environmental performance of in-use vehicles. Energies 11(1):221

23. Shaikh SM, Doijad RC, Shete AS, Sankpal PS (2016) A review on: Preservatives used in pharmaceuticals and impacts on Health. PharmaTutor 4(5):25-34

24. Mathew E, Pitzanti G, Larrañeta E, Lamprou DA (2020) 3D printing of pharmaceuticals and drug delivery devices. Pharmaceutics 12(3):266

25. Sen K, Mukherjee R, Sansare S, Halder A, Kashi H, Ma AW, Chaudhuri B (2021) Impact of powder-binder interactions on 3D printability of pharmaceutical tablets using drop test methodology. Eur J Pharm Sci 160:105755

26. Cao Q-R, Choi Y-W, Cui J-H, Lee B-J (2005) Effect of solvents on physical properties and release characteristics of monolithic hydroxypropylmethylcellulose matrix granules and tablets. Arch Pharm Res 28(4):493-501

27. Grodowska K, Parczewski A (2010) Organic solvents in the pharmaceutical industry. Acta Pol Pharm 67(1):3-12

28. Liu Y, Fang J, Tong X, Huan C, Ji G, Zeng Y, Xu L, Yan Z (2019) Change to biogas production in solid-state anaerobic digestion using rice straw as substrates at different temperatures. Bioresour Technol 293:122066

29. Alzeer J, Abou Hadeed K (2016) Ethanol and its Halal status in food industries. Trends Food Sci Technol 58:14-20

30. Tiwari G, Sharma S, Prasad R (2015) Bioethanol production: future prospects from non-traditional sources in India. Int $\mathrm{J}$ Res BioSci 4(4):1-15

31. Gorgus E, Hittinger M, Schrenk D (2016) Estimates of ethanol exposure in children from food not labeled as alcohol-containing. J Anal Toxicol 40(7):537-542
32. Jiang W-x, Qi J-R, Liao J-s, Yang X-q (2021) Acid/ethanol induced pectin gelling and its application in emulsion gel. Food Hydrocolloids 118:106774

33. Zhu L, Deng G, Xiao F (2012) Ethanol-based ink composition. US Patent: US 8,110,031 B2

34. Tajmamet J, Keuleers RRF, Lascaux M-E, Sachdev SA, Rane VS (2015) Cleaning and disinfecting liquid hand dishwashing detergent comprising a benzyl alcohol/ethanol mixture. US Patent: US $8,993,500$ B2

35. Dréno B, Zuberbier T, Gelmetti C, Gontijo G, Marinovich M (2019) Safety review of phenoxyethanol when used as a preservative in cosmetics. J Eur Acad Dermatol Venereol 33:15-24

36. Baij L, Buijs J, Hermans JJ, Raven L, Iedema PD, Keune K, Sprakel J (2020) Quantifying solvent action in oil paint using portable laser speckle imaging. Sci Rep 10(1):1-12

37. Fred T, Sophia K, Alex S, Emmanuel B, Tom L, Lucas A (2020) Comparison of antibacterial efficacy of locally produced alcohol based hand sanitizer and commonly available commercial hand sanitizer used in healthcare facilities in Uganda. Open Access Library J 7(4):1-13

38. Haft RJ, Keating DH, Schwaegler T, Schwalbach MS, Vinokur J, Tremaine M, Peters JM, Kotlajich MV, Pohlmann EL, Ong IM (2014) Correcting direct effects of ethanol on translation and transcription machinery confers ethanol tolerance in bacteria. Proc Natl Acad Sci 111(25):E2576-E2585

39. Siddharta A, Pfaender S, Vielle NJ, Dijkman R, Friesland M, Becker B, Yang J, Engelmann M, Todt D, Windisch MP (2017) Virucidal activity of World Health Organization-recommended formulations against enveloped viruses, including Zika, Ebola, and emerging coronaviruses. J Infect Dis 215(6):902-906

40. Trott AT (2012) Wounds and lacerations-e-book: emergency care and closure. Elsevier Saunders, Philadelphia, PA

41. Lim K-S, Kam P (2008) Chlorhexidine-pharmacology and clinical applications. Anaesth Intensive Care 36(4):502-512

42. Noor S (2016) Chlorhexidine: its properties and effects. Res J Pharm Technol 9(10):1755-1760

43. Robertson WO (2003) Poisoning and toxicology handbook. Critical Care Medicine 31(5):1605

44. Bondurant S, McKinney T, Bondurant L, Fitzpatrick L (2020) Evaluation of a benzalkonium chloride hand sanitizer in reducing transient Staphylococcus aureus bacterial skin contamination in health care workers. Am J Infect Control 48(5):522-526

45. Wentworth AB, Yiannias JA, Davis MD, Killian JM (2016) Benzalkonium chloride: a known irritant and novel allergen. Dermatitis 27(1):14-20

46. Kakurinov V (2014) Encyclopedia of Food Safety. Volume 4. Elsevier; New York, NY, USA. Food safety assurance systems: cleaning and disinfection, pp. 211-225

47. Chowdhury D, Rahman A, Hu H, Jensen SO, Deva AK, Vickery K (2019) Effect of disinfectant formulation and organic soil on the efficacy of oxidizing disinfectants against biofilms. J Hosp Infect 103(1):e33-e41

48. Tenebe I, Nnaji C, Emenike P, Ngene B (2020) Efficacy of disinfectants and brand reputation on bathing water quality improvement. Environ Nanotechnol Monitor Manag 14:100330

49. McDonnell G, Russell AD (1999) Antiseptics and disinfectants: activity, action, and resistance. Clin Microbiol Rev 12(1):147-179

50. Moorer W (2003) Antiviral activity of alcohol for surface disinfection. Int J Dent Hyg 1(3):138-142

51. Naoura G, Emendack Y, Baloua N, Vom Brocke K, Hassan MA, Sawadogo N, Nodjasse AD, Djinodji R, Trouche G, Laza HE (2020) Characterization of semi-arid Chadian sweet sorghum accessions as potential sources for sugar and ethanol production. Sci Rep 10(1):1-11

52. Marzo C, Díaz AB, Caro I, Blandino A (2019) Status and perspectives in bioethanol production from sugar beet. In: Ray RC, 
Ramachandran S (eds) Bioethanol production from food crops. Academic Press, pp 61-79

53. Wu R, Chen D, Cao S, Lu Z, Huang J, Lu Q, Chen Y, Chen X, Guan N, Wei Y (2020) Enhanced ethanol production from sugarcane molasses by industrially engineered Saccharomyces cerevisiae via replacement of the PHO4 gene. RSC Adv 10(4): 2267-2276

54. Raharja R, Murdiyatmo U, Sutrisno A, Wardani A (2019) Bioethanol production from sugarcane molasses by instant dry yeast. E\&ES 230(1):012076

55. Inamdar $\mathrm{S}$ (1994) Economics of molasses to ethanol in India. Appl Biochem Biotechnol 45:723-725

56. Nofemele Z, Shukla P, Trussler A, Permaul K, Singh S (2012) Improvement of ethanol production from sugarcane molasses through enhanced nutrient supplementation using Saccharomyces cerevisiae. J Brew Distill 3(2):29-35

57. Maiti B, Rathore A, Srivastava S, Shekhawat M, Srivastava P (2011) Optimization of process parameters for ethanol production from sugar cane molasses by Zymomonas mobilis using response surface methodology and genetic algorithm. Appl Microbiol Biotechnol 90(1):385-395

58. Guigou M, Lareo C, Pérez LV, Lluberas ME, Vázquez D, Ferrari MD (2011) Bioethanol production from sweet sorghum: Evaluation of post-harvest treatments on sugar extraction and fermentation. Biomass Bioenergy 35(7):3058-3062

59. Castro E, Nieves IU, Rondón V, Sagues WJ, Fernández-Sandoval MT, Yomano LP, York SW, Erickson J, Vermerris W (2017) Potential for ethanol production from different sorghum cultivars. Ind Crop Prod 109:367-373

60. Ratnavathi C, Suresh K, Kumar BV, Pallavi M, Komala V, Seetharama N (2010) Study on genotypic variation for ethanol production from sweet sorghum juice. Biomass Bioenergy 34(7):947-952

61. Ray RC, Uppuluri KB, Trilokesh C, Lareo C (2019) Sweet sorghum for bioethanol production: scope, technology, and economics. In: Ray RC, Ramachandran S (eds) Bioethanol production from food crops. Academic Press, pp 81-100

62. Fernandes G, Braga TG, Fischer J, Parrella RA, de Resende MM, Cardoso VL (2014) Evaluation of potential ethanol production and nutrients for four varieties of sweet sorghum during maturation. Renew Energy 71:518-524

63. Mohanty SK, Swain MR (2019) Bioethanol production from corn and wheat: food, fuel, and future. In: Ray RC, Ramachandran S (eds) Bioethanol production from food crops. Academic Press, pp 45-59

64. Sharma A, Bhargava R (2016) "Production of biofuel (ethanol) from cand co product evolution": a review. IRJET 3(12):745-749

65. Mosier NS, Ileleji KE (2020) How fuel ethanol is made from corn. In: Dahiya A (ed) Bioenergy 2nd ed. Academic Press, pp 539-544

66. Jansson C, Westerbergh A, Zhang J, Hu X, Sun C (2009) Cassava, a potential biofuel crop in (the) People's Republic of China. Appl Energy 86:S95-S99

67. Benvenga MAC, Librantz AFH, Santana JCC, Tambourgi EB (2016) Genetic algorithm applied to study of the economic viability of alcohol production from Cassava root from 2002 to 2013. J Clean Prod 113:483-494

68. Anyanwu C, Ibeto C, Ezeoha S, Ogbuagu N (2015) Sustainability of cassava (Manihot esculenta Crantz) as industrial feedstock, energy and food crop in Nigeria. Renew Energy 81:745-752

69. Marx S (2019) Cassava as feedstock for ethanol production: a global perspective. In: Ray RC, Ramachandran S (eds) Bioethanol production from food crops. Academic Press, pp 101-113

70. Lomthong T, Lertwattanasakul N, Kitpreechavanich V (2016) Production of raw starch degrading enzyme by the thermophilic filamentous bacterium Laceyella sacchari LP175 and its application for ethanol production from dried cassava chips. Starch-Stärke 68(11-12):1264-1274

71. Khamkeaw A, Phisalaphong M (2016) Hydrolysis of cassava starch by co-immobilized multi-microorganisms of Loog-Pang (Thai rice cake starter) for ethanol fermentation. Food Sci Biotechnol 25(2):509-516

72. Lareo C, Ferrari MD (2019) Sweet potato as a bioenergy crop for fuel ethanol production: perspectives and challenges. In: Ray RC, Ramachandran S (eds) Bioethanol production from food crops. Academic Press, pp 115-147

73. Shekhar S, Mishra D, Buragohain AK, Chakraborty S, Chakraborty N (2015) Comparative analysis of phytochemicals and nutrient availability in two contrasting cultivars of sweet potato (Ipomoea batatas L.). Food Chem 173:957-965

74. Szambelan K, Nowak J, Szwengiel A, Jeleń H, Łukaszewski G (2018) Separate hydrolysis and fermentation and simultaneous saccharification and fermentation methods in bioethanol production and formation of volatile by-products from selected corn cultivars. Ind Crop Prod 118:355-361

75. Ziska LH, Runion GB, Tomecek M, Prior SA, Torbet HA, Sicher R (2009) An evaluation of cassava, sweet potato and field corn as potential carbohydrate sources for bioethanol production in Alabama and Maryland. Biomass Bioenergy 33(11):1503-1508

76. Duvernay WH, Chinn MS, Yencho GC (2013) Hydrolysis and fermentation of sweetpotatoes for production of fermentable sugars and ethanol. Ind Crop Prod 42:527-537

77. Zhang L, Zhao H, Gan M, Jin Y, Gao X, Chen Q, Guan J, Wang Z (2011) Application of simultaneous saccharification and fermentation (SSF) from viscosity reducing of raw sweet potato for bioethanol production at laboratory, pilot and industrial scales. Bioresour Technol 102(6):4573-4579

78. Lareo C, Ferrari MD, Guigou M, Fajardo L, Larnaudie V, Ramírez MB, Martínez-Garreiro J (2013) Evaluation of sweet potato for fuel bioethanol production: hydrolysis and fermentation. SpringerPlus 2(1):493

79. Cao Y, Tian H, Yao K, Yuan Y (2011) Simultaneous saccharification and fermentation of sweet potato powder for the production of ethanol under conditions of very high gravity. Front Chem Sci Eng 5(3):318-324

80. Rai R, Bibra M, Chadha B, Sani RK (2019) Enhanced hydrolysis of lignocellulosic biomass with doping of a highly thermostable recombinant laccase. Int J Biol Macromol 137:232-237

81. Rai R, Kaur B, Chadha B (2016) A method for rapid purification and evaluation of catalytically distinct lignocellulolytic glycosyl hydrolases from thermotolerant fungus Acrophialophora sp. Renew Energy 98:254-263

82. Yuan H-w, Tan L, Kida K, Morimura S, Sun Z-Y, Tang Y-Q (2021) Potential for reduced water consumption in biorefining of lignocellulosic biomass to bioethanol and biogas. J Biosci Bioeng 131(5):461-468

83. Lugani Y, Sooch BS, Kumar S (2019) Biochemical strategies for enhanced biofuel production. In: Rastegari A, Yadav A, Gupta A (eds) Prospects of renewable bioprocessing in future energy systems. Springer, Cham, pp 51-87

84. Karagoz P, Bill RM, Ozkan M (2019) Lignocellulosic ethanol production: evaluation of new approaches, cell immobilization and reactor configurations. Renew Energy 143:741-752

85. Hans M, Garg S, Pellegrini VO, Filgueiras JG, de Azevedo ER, Guimaraes FE, Chandel AK, Polikarpov I, Chadha BS, Kumar S (2020) Liquid ammonia pretreatment optimization for improved release of fermentable sugars from sugarcane bagasse. J Clean Prod 281:123922

86. Robak K, Balcerek M (2020) Current state-of-the-art in ethanol production from lignocellulosic feedstocks. Microbiol Res 240: 126534 
87. Kumar S, Singh SP, Mishra IM, Adhikari DK (2009) Ethanol and xylitol production from glucose and xylose at high temperature by Kluyveromyces sp. IIPE453. J Ind Microbiol Biotechnol 36(12):1483

88. Hans M, Kumar S (2019) Biohythane production in two-stage anaerobic digestion system. Int J Hydrog Energy 44(32):17363-17380

89. Zhao G, Kuang G, Wang Y, Yao Y, Zhang J, Pan Z-H (2020) Effect of steam explosion on physicochemical properties and fermentation characteristics of sorghum (Sorghum bicolor (L.) Moench). LWT 129:109579

90. Chandel AK, Garlapati VK, Jeevan Kumar S, Hans M, Singh AK, Kumar S (2020) The role of renewable chemicals and biofuels in building a bioeconomy. Biofuels Bioprod Biorefin 14(4):830-844

91. Arora A, Priya S, Sharma P, Sharma S, Nain L (2016) Evaluating biological pretreatment as a feasible methodology for ethanol production from paddy straw. Biocatal Agric Biotechnol 8:66-72

92. Asgher M, Wahab A, Bilal M, Iqbal HMN (2016) Lignocellulose degradation and production of lignin modifying enzymes by Schizophyllum commune IBL-06 in solid-state fermentation. Biocatal Agric Biotechnol 6:195-201

93. Choudhary J, Singh S, Nain L (2017) Bioprospecting thermotolerant ethanologenic yeasts for simultaneous saccharification and fermentation from diverse environments. J Biosci Bioeng 123(3):342-346

94. Jahnavi G, Prashanthi GS, Sravanthi K, Rao LV (2017) Status of availability of lignocellulosic feed stocks in India: biotechnological strategies involved in the production of bioethanol. Renew Sust Energ Rev 73:798-820

95. Escaramboni B, Núñez EGF, Carvalho AFA, de Oliva NP (2018) Ethanol biosynthesis by fast hydrolysis of cassava bagasse using fungal amylases produced in optimized conditions. Ind Crop Prod 112: 368-377

96. de Souza PK, Battisti R, Souza O, Sellin N, Machado RAF, Marangoni $C$ (2021) Integration of banana crop residues as biomass feedstock into conventional production of first-generation fuel ethanol from sugarcane: a simulation-based case study. Biofuels Bioprod Biorefin 15(3):671-689

97. Chandel AK, Antunes FA, Silva MB, da Silva SS (2013) Unraveling the structure of sugarcane bagasse after soaking in concentrated aqueous ammonia (SCAA) and ethanol production by Scheffersomyces (Pichia) stipitis. Biotechnol Biofuels 6(1):1-11

98. Gao Y, Xu J, Yuan Z, Jiang J, Zhang Z, Li C (2018) Ethanol production from sugarcane bagasse by fed-batch simultaneous saccharification and fermentation at high solids loading. Energy Sci Eng 6(6):810-818

99. Arora R, Behera S, Sharma NK, Singh R, Yadav YK, Kumar S (2014) Biochemical conversion of rice straw (Oryza sativa L.) to bioethanol using thermotolerant isolate $\mathrm{K}$. marxianus NIRE-K3. In: Sharma NR et al. (eds) Proceedings of exploring and basic sciences for Next Generation Frontiers. Elsevier, New Delhi, pp 143-146

100. Ballesteros I, Negro MJ, Oliva JM, Cabañas A, Manzanares P, Ballesteros M (2006) Ethanol production from steam-explosion pretreated wheat straw. In: McMillan JD, Adney WS, Mielenz JR, Klasson KT (eds) Twenty-seventh symposium on biotechnology for fuels and chemicalsed. Humana Press, pp 496-508

101. Lugani Y, Rai R, Prabhu AA, Maan P, Hans M, Kumar V, Kumar S, Chandel AK, Sengar R (2020) Recent advances in bioethanol production from lignocelluloses: a comprehensive review with a focus on enzyme engineering and designer biocatalysts. Biofuel Res J 7(4):1267-1295

102. Onuki S, Koziel JA, Jenks WS, Cai L, Grewell D, van Leeuwen J (2016) Taking ethanol quality beyond fuel grade: a review. J Inst Brew 122(4):588-598

103. Bušić A, Marđetko N, Kundas S, Morzak G, Belskaya H, Ivančić Šantek M, Komes D, Novak S, Šantek B (2018) Bioethanol production from renewable raw materials and its separation and purification: a review. Food Technol Biotechnol 56(3):289-311

104. Biasi LC, Batista FR, Zemp RJ, Romano AL, Heinkenschloss M, Meirelles AJ (2021) Parastillation and metastillation applied to bioethanol and neutral alcohol purification with energy savings. Chem Eng Process-Process Intensific 162:108334

105. Löffler H, Kampf G, Schmermund D, Maibach H (2007) How irritant is alcohol? Br J Dermatol 157(1):74-81

106. Angelova-Fischer I, Dapic I, Hoek A-K, Jakasa I, Fischer TW, Zillikens D, Kezic S (2014) Skin barrier integrity and natural moisturising factor levels after cumulative dermal exposure to alkaline agents in atopic dermatitis. Acta Derm Venereol 94(6):640-644

107. Misteli H, Weber WP, Reck S, Rosenthal R, Zwahlen M, Fueglistaler P, Bolli MK, Oertli D, Widmer AF, Marti WR (2009) Surgical glove perforation and the risk of surgical site infection. Arch Surg 144(6):553-558

108. Guin JD, Goodman J (2001) Contact urticaria from benzyl alcohol presenting as intolerance to saline soaks. Contact Dermatitis 45(3): 182-183

109. Lachenmeier DW (2008) Safety evaluation of topical applications of ethanol on the skin and inside the oral cavity. J Occup Med Toxicol 3(1):26

110. Erasmus V, Daha TJ, Brug H, Hendrik Richardus J, Behrendt MD, Vos MC, van Beeck EF (2010) Systematic review of studies on compliance with hand hygiene guidelines in hospital care. Infect Control Hosp Epidemiol 31(3):283-294

111. Jing JLJ, Pei Yi T, Bose RJ, McCarthy JR, Tharmalingam N, Madheswaran $T$ (2020) Hand sanitizers: a review on formulation aspects, adverse effects, and regulations. Int J Environ Res Public Health 17(9):3326

112. Winnefeld M, Richard M, Drancourt M, Grob J (2000) Skin tolerance and effectiveness of two hand decontamination procedures in everyday hospital use. Br J Dermatol 143(3):546-550

113. Bessonneau V, Clément M, Thomas O (2010) Can intensive use of alcohol-based hand rubs lead to passive alcoholization? Int $\mathrm{J}$ Environ Res Public Health 7(8):3038-3050

114. Maier A, Ovesen JL, Allen CL, York RG, Gadagbui BK, Kirman CR, Poet T, Quiñones-Rivera A (2015) Safety assessment for ethanol-based topical antiseptic use by health care workers: evaluation of developmental toxicity potential. Regul Toxicol Pharmacol 73(1):248-264

115. Yokoyama A, Omori T (2003) Genetic polymorphisms of alcohol and aldehyde dehydrogenases and risk for esophageal and head and neck cancers. Jpn J Clin Oncol 33(3):111-121

116. Miller MA, Rosin A, Levsky ME, Patel MM, Gregory TJ, Crystal CS (2006) Does the clinical use of ethanol-based hand sanitizer elevate blood alcohol levels? A prospective study. Am J Emerg Med 24(7):815-817

117. Reisfield GM, Goldberger BA, Crews BO, Pesce AJ, Wilson GR, Teitelbaum SA, Bertholf RL (2011) Ethyl glucuronide, ethyl sulfate, and ethanol in urine after sustained exposure to an ethanolbased hand sanitizer. J Anal Toxicol 35(2):85-91

118. Salomone A, Bozzo A, Di Corcia D, Gerace E, Vincenti M (2018) Occupational exposure to alcohol-based hand sanitizers: the diagnostic role of alcohol biomarkers in hair. J Anal Toxicol 42(3): $157-162$

119. Yangzes S, Grewal S, Gailson T, Grewal SPS (2021) Hand sanitizer-induced ocular injury: a COVID-19 hazard in children. JAMA Ophthalmol 139(3):362-364

Publisher's Note Springer Nature remains neutral with regard to jurisdictional claims in published maps and institutional affiliations. 